\title{
Loss of $p 53$ Induces Changes in the Behavior of Subventricular Zone Cells: Implication for the Genesis of Glial Tumors
}

\author{
Sara Gil-Perotin, ${ }^{1,2}$ Mireya Marin-Husstege, ${ }^{1}$ Jiadong Li, ${ }^{1}$ Mario Soriano-Navarro, ${ }^{2,3}$ Frederique Zindy, \\ Martine F. Roussel, ${ }^{4 \star}$ Jose-Manuel Garcia-Verdugo, ${ }^{2,3 *}$ and Patricia Casaccia-Bonnefil ${ }^{1}$ \\ ${ }^{1}$ Department Neuroscience and Cell Biology, Robert Wood Johnson Medical School, Piscataway, New Jersey 08854, ${ }^{2}$ Department Comparative \\ Neurobiology, Instituto Cavanilles, University of Valencia, 46980 Valencia, Spain, ${ }^{3}$ Department of Cellular Therapy, Centro de Investigación Príncipe Felipe, \\ Valencia, 46013 Valencia, Spain, and ${ }^{4}$ Department of Tumor Cell Biology and Genetics, St. Jude Children's Research Hospital, Memphis, Tennessee 38105
}

The role of multipotential progenitors and neural stem cells in the adult subventricular zone (SVZ) as cell-of-origin of glioblastoma has been suggested by studies on human tumors and transgenic mice. However, it is still unknown whether glial tumors are generated by all of the heterogeneous SVZ cell types or only by specific subpopulations of cells. It has been proposed that transformation could result from lack of apoptosis and increased self-renewal, but the definition of the properties leading to neoplastic transformation of SVZ cells are still elusive. This study addresses these questions in mice carrying the deletion of $p 53$, a tumor-suppressor gene expressed in the SVZ. We show here that, although loss of $p 53$ by itself is not sufficient for tumor formation, it provides a proliferative advantage to the slow- and fast-proliferating subventricular zone (SVZ) populations associated with their rapid differentiation. This results in areas of increased cell density that are distributed along the walls of the lateral ventricles and often associated with increased $p 53$-independent apoptosis. Transformation occurs when loss of $p 53$ is associated with a mutagenic stimulus and is characterized by dramatic changes in the properties of the quiescent adult SVZ cells, including enhanced self-renewal, recruitment to the fast-proliferating compartment, and impaired differentiation.

Together, these findings provide a cellular mechanism for how the slow-proliferating SVZ cells can give rise to glial tumors in the adult brain.

Key words: differentiation; proliferation; subependymal zone; glia; neurogenesis; cell cycle

\section{Introduction}

Relatively quiescent neural stem cells and fast-proliferating multipotential progenitors residing in the adult SVZ are characterized by the ability to self-renew and generate distinct cell types (Galli et al., 2003; Alvarez-Buylla and Lim, 2004), thus providing an important therapeutic tool (Picard-Riera et al., 2004). Given their ability to proliferate, self-renew, and migrate, these cells have also the potential to undergo neoplastic transformation ( $\mathrm{Re}$ cht et al., 2003), and a large body of evidence supports this concept, although the identity of the transformed cells is not well defined (Rao, 1999; Holland, 2000; Berger et al., 2004; Jang et al., 2004). Four distinct cell types reside in the adult SVZ (Doetsch et

Received Sept. 19, 2005; revised Nov. 18, 2005; accepted Dec. 7, 2005.

This work was supported by National Institutes of Health Grant NS42925, New Jersey Cancer Commission Grant 05-2414-CCR-E0, and National Multiple Sclerosis Society Grant RG 3553-A5 (P.C.-B.), National Cancer Institute Grants CA096832 and CA71907 and Children's Brain Tumor Foundation (M.F.R.), Instituto de Salud Carlos III (ISCIII), Madrid Grant G03-056 (J.-M.G.-V.), and Fellowship ISCIII, Reference 01/9513 (S.G.-P.). We thank Dr. A. Berns for the $p 53^{\text {flox/flox }}$ mice, Dr. C. Eberhart for histological evaluation of the tumors, Dr. J. Downing for retroviral constructs, Dr. C. Sherr, Dr. S. Baker, and Dr. F. Doetsch for critical comments, Dr. A. Alvarez-Buylla for initial encouragement and support, S. Wilkerson, and P. Abano for animal care and genotyping.

${ }^{*} M . F$. R. and J.-M.G.-V. contributed equally to this work.

Correspondence should be addressed to Patrizia Casaccia-Bonnefil, Department Neuroscience, R-304, Robert Wood Johnson Medical School, 675 Hoes Lane, Piscataway, NJ 08854. E-mail: casaccpa@umdnj.edu.

DOI:10.1523/JNEUROSCI.3970-05.2006

Copyright $\odot 2006$ Society for Neuroscience $\quad$ 0270-6474/06/261107-10\$15.00/0 al., 1997, 1999a,b). The ependymal cells (type E cells) provide the lining of the lumen of the ventricles and are important for regulating the flow of the CSF. The astrocyte-like type B cells are characterized by the presence of intermediate filaments and nestin-positive $(+) / \mathrm{GFAP}^{+}$immunoreactivity (Doetsch et al., 1997), and they have the property of self-renewal (Doetsch et al., 2002a) and proliferate very slowly (Morshead et al., 1994). Type $\mathrm{C}$ cells are large cells with invaginated nuclei and lack of intermediate filaments. These cells have also been called "transit amplifying progenitors," because they proliferate rapidly and give rise to migratory polysialylated neural cell adhesion molecule (PSANCAM)-positive neuroblasts (Lois and Alvarez-Buylla, 1994; Doetsch et al., 1997; Peretto et al., 1999) and oligodendrocyte progenitors (Nait-Oumesmar et al., 1999; Vitry et al., 2001).

The importance of SVZ cells in the genesis of glioblastomas (Recht et al., 2003) has been suggested by the isolation of neurosphere-forming cells from human glioblastomas (Ignatova et al., 2002) and by studies on transgenic mice (Holland, 2000) and on animals prenatally exposed to the mutagen $\mathrm{N}$-ethyl- $\mathrm{N}$ nitrosourea (ENU) (Oda et al.,1997; Leonard et al., 2001; Slikker et al., 2004; Savarese et al., 2005).

p53 is a tumor-suppressor gene expressed in SVZ cells (van Lookeren Campagne and Gill, 1998; Jori et al., 2003) and frequently deleted or mutated in adult (von Deimling et al.,1992; 
Watanabe et al., 1996; Hayashi et al., 2004) and pediatric glial tumors (Sung et al., 2000; Di Sapio et al., 2002). However, it is still not known whether loss of $p 53$ can alter the behavior of adult SVZ cells and induce specific changes in specific subpopulations leading tumor formation. This study is aimed at testing this hypothesis.

\section{Materials and Methods}

Animals. All of the experiments were performed in 8- to 12 -week-old mice obtained from Trp53 ${ }^{\text {Tm1Tyj }}$ C57BL/6J heterozygous (i.e., $p 53^{+/-}$) breeding pairs. Mouse genotypes were confirmed by tail clipping and PCR using the primers 5' -ACAGCGTGGTGGTACCTTAT-3 (ImRo36), 5'-TATACTCAGAGCCGGCCT-3' (ImRo37), and 5' -TCCTCGTGCTTTACGGTATC-3' (neo), yielding a fragment of $375 \mathrm{bp}$ for $p 53^{+/+}$ and 525 bp in $p 53^{-/-}$mice. $p 53^{\text {flox/flox }}$ mice (a gift from Dr. Anton Berns, Netherlands Cancer Institute, Amsterdam, The Netherlands) were genotyped using the primers $5^{\prime}$-CACAAAAACAGGTTAAACCCAG-3' and 5'-AGCACATAGGAGGCAGAGAC-3', yielding a fragment of $370 \mathrm{bp}$ for $p 53^{\text {flox/flox }}$ and 288 bp for wild-type mice.

Irradiation. A total dose of 2.21 Gy was used for brain irradiation using a linear accelerator with $6 \mathrm{MV}$ of nominal photon energy (Chow et al., 2000). Anesthetized mice were placed in a prone position on an expanded polystyrene bed at a distance of $99.5 \mathrm{~cm}$ from the source. The dose variation within the target volume was estimated to be $\pm 5 \%$. Four hours after irradiation, the animals were perfused with $10 \%$ neutral buffered formalin.

ENU injection. Timed-pregnant $p 53^{+/-}$females were injected with ENU ( $25 \mathrm{mg} / \mathrm{kg}$ body weight) as described previously (Leonard et al., 2001). The offspring were allowed to reach $6-8$ weeks of age and were then killed.

Protein extracts and Western blot analysis. The SVZ was dissected and homogenized in cold lysis buffer $(50 \mathrm{~mm}$ Tris- $\mathrm{HCl}, \mathrm{pH} 7.4$, containing $150 \mathrm{~mm} \mathrm{NaCl}, 1 \%$ Triton X-100, $0.25 \%$ sodium deoxycholate, $1 \mathrm{~mm}$ EDTA, $0.1 \%$ SDS, $1 \mathrm{~mm}$ PMSF, and $5 \mu \mathrm{g} / \mathrm{ml}$ of the protease inhibitors aprotinin and leupeptin). Tissue extracts were sonicated and centrifuged at $14,000 \times g$ for $15 \mathrm{~min}$ at $4^{\circ} \mathrm{C}$. Proteins were measured using a detergent-compatible assay (Bio-Rad, Hercules, CA) with bovine serum albumin as protein standard, separated by SDS-PAGE, and transferred to nitrocellulose (Hybond ECL; Amersham Biosciences, Buckinghamshire, UK). Immunoblotting was performed using a rabbit anti- $p 53$ polyclonal antibody (FL-393; Santa Cruz Biotechnology, Santa Cruz, CA) at a 1:500 dilution. Mouse anti-actin monoclonal antibody (Sigma, St. Louis, MO) was used at a 1:1000 dilution. After incubation of secondary antibodies, immunoreactive bands were visualized using ECL plus (Amersham Biosciences).

RNA extraction and reverse transcription-PCR. Freshly dissected SVZ regions were homogenized in Trizol reagent. RNA was isolated using the RNeasy Mini kit (Qiagen, Hilden, Germany). Total RNA at $1.5 \mu \mathrm{g}$ was reverse transcribed and then amplified using SuperScript reverse transcription (RT)-PCR kit (Invitrogen, Carlsbad, CA). The following primers were used: 5'-CATCACCTCACTGCATGGAC-3' and 5' CTTGTGTACGGCGGTCTCTC-3' to amplify $p 53$; and $5^{\prime}$-TGGAATCCTGTGGCATCC-3' and 5' -TCGTACTCCTGCTTGCTG-3 to amplify actin.

Bromodeoxyuridine immunohistochemistry. Bromodeoxyuridine (BrdU) (Sigma) was injected intraperitoneally (100 $\mu \mathrm{g} / \mathrm{g}$ body weight). At the indicated times (either $1 \mathrm{~h}$ or 2 weeks later), mice were anesthetized and perfused with $4 \%$ paraformaldehyde (PFA). Brain tissues were sectioned and then processed for immunohistochemistry. $\mathrm{BrdU}^{+}$cells were counted in at least four sections for each animal and expressed per squared millimeter. For data analysis, we used nonparametric statistics (Mann-Whitney $U$ test) because we could not assume a normal distribution for our data. The previously described function of $p 53$ as cell cycle inhibitor suggested that $p 53$ loss-of-function would increase (and not decrease) the number of cells in S-phase. Thus, we performed planned one-tailed comparisons. Significance level for the rejection of the null hypothesis was set at $\alpha=0.05$.

Thymidine labeling and autoradiography. $p 53^{+/+}$and $p 53^{-/-}$litter-
A
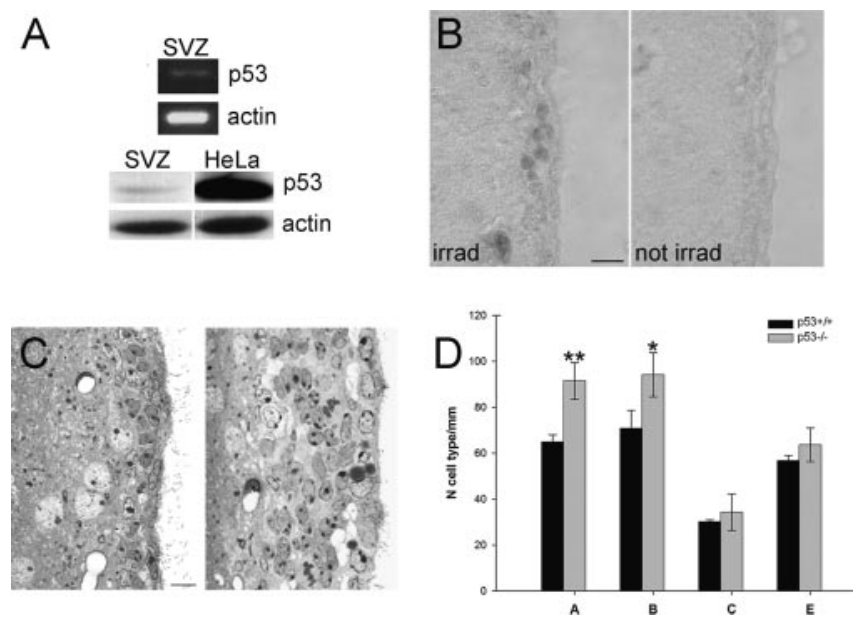

Figure 1. Loss of $p 53$ increases the number of adult neural stem cells and neuroblasts. $\boldsymbol{A}$, RT-PCR (top) for the detection of $p 53$ mRNA in adult mouse SVZ and Western blot (bottom) for the detection of $p 53$ protein in SVZ protein extracts. Note the weak band detected in the SVZ extracts compared with HeLa cells. Actin was used as loading control. $\boldsymbol{B}$, Detail of the lateral wall of the ventricle in irradiated (irrad) and not irradiated (not irrad) C57BL/6 wild-type mice. Note that $p 53$ immunoreactivity after irradiation was restricted to cells of the SVZ, whereas the ependymal cells lining the lumen of the ventricles were not immunoreactive. Scale bar, $10 \mu \mathrm{m}$. C, Semithin sections of the SVZ in $p 53^{+1+}$ and $p 53^{-/-}$mice stained with toluidine blue showing the thickening of the cellular layer. Scale bar, $25 \mu \mathrm{m}$. $\boldsymbol{D}$, Bar graph of the average number of SVZ cells identified per unit length in $p 53^{+/+}$(blackbars; $n=5$ ) and $p 53^{-/-}$(gray bars; $n=5$ ) mice. ${ }^{*} p<0.25{ }^{* *} p<0.01$.

mates were injected with $50 \mu \mathrm{l}$ of $6.7 \mathrm{mCi}$ titrated $\left[{ }^{3} \mathrm{H}\right.$ ] thymidine (Thy) (Amersham Biosciences) as described previously (Doetsch et al., 2002b). After $1 \mathrm{~h}$ or 4 weeks after injection, mice were perfused with $0.9 \%$ saline, followed by Karnovsky's fixative (2\% paraformaldehyde and $2.5 \%$ glutaraldehyde). Heads were removed and postfixed in the same fixative overnight, and the brains were dissected, washed in $0.1 \mathrm{~m}$ phosphate buffer, and cut into $200 \mu \mathrm{m}$ vibratome sections. Sections were postfixed in $2 \%$ osmium and embedded in Araldite (Durcupan; Fluka, Buchs, Switzerland). Semithin sections $(1.5 \mu \mathrm{m})$ were processed for titrated autoradiography (Doetsch et al., 2002b). $\left[{ }^{3} \mathrm{H}\right] \mathrm{Thy}{ }^{+}$cells were counted in five sections, one every $7.5 \mu \mathrm{m}$, and the means were calculated and extrapolated per squared millimeter. Statistical analysis was performed as described for BrdU.

Terminal deoxynucleotidyl transferase-mediated biotinylated UTP nick end labeling in vivo and in vitro. $p 53^{+/+}$and $p 53^{-/-}$mice were perfused with $4 \%$ PFA. Brains were removed, cryopreserved in 30\% sucrose, and sectioned. Cells or sections were treated with ethanol acetic (2:1) for 10 min at $-20^{\circ} \mathrm{C}$, washed three times in PBS, and processed with Apoptag Plus Fluorescein In Situ Detection kit (Chemicon, Temecula, CA) according to the manufacturer.

Immunohistochemistry and immunocytochemistry. For O4 staining in cells, cultures were gently rinsed in PBS (10 mM sodium phosphate, $\mathrm{pH}$ 7.4, and $150 \mathrm{~mm} \mathrm{NaCl}$ ) and incubated with hybridoma supernatant (1: 10; a gift from Dr. Bansal, University of Farmington, Farmington, CT) for $30 \mathrm{~min}$ at $37^{\circ} \mathrm{C}$ before fixation with $4 \%$ PFA for $20 \mathrm{~min}$ at room temperature. For immunocytochemical and immunohistochemical procedures, the following primary antibodies were used: anti- $\beta$-tubulin III (1:500, clone Tuj1; Covance, Berkeley, CA), anti-GFAP [mouse, 1:1000 (Sternberg Monoclonals, Lutherville, MD) or rabbit, 1:1000 (Dako, Glostrup, Denmark)], CC1 antibody (mouse, 1:50; Oncogene, San Diego, CA), anti-PSA-NCAM (mouse, 1:400; AbCys, Paris, France), antiBrdU (mouse, 1:200; Dako), anti-p53 (rabbit, 1:500 CM5; Novocastra, New Castle upon Tyne, UK), anti-nestin (rat-401, 1:1000; Developmental Studies Hybridoma Bank, University of Iowa, Iowa City, IA), and anti-Cre (rabbit, 1:3000; Covance). Incubation of all of the primary antibodies was followed by incubation with the appropriate secondary antibodies conjugated with fluorophores (Jackson ImmunoResearch, West Grove, PA) or with biotin (Vector Laboratories, Burlingame, CA). 

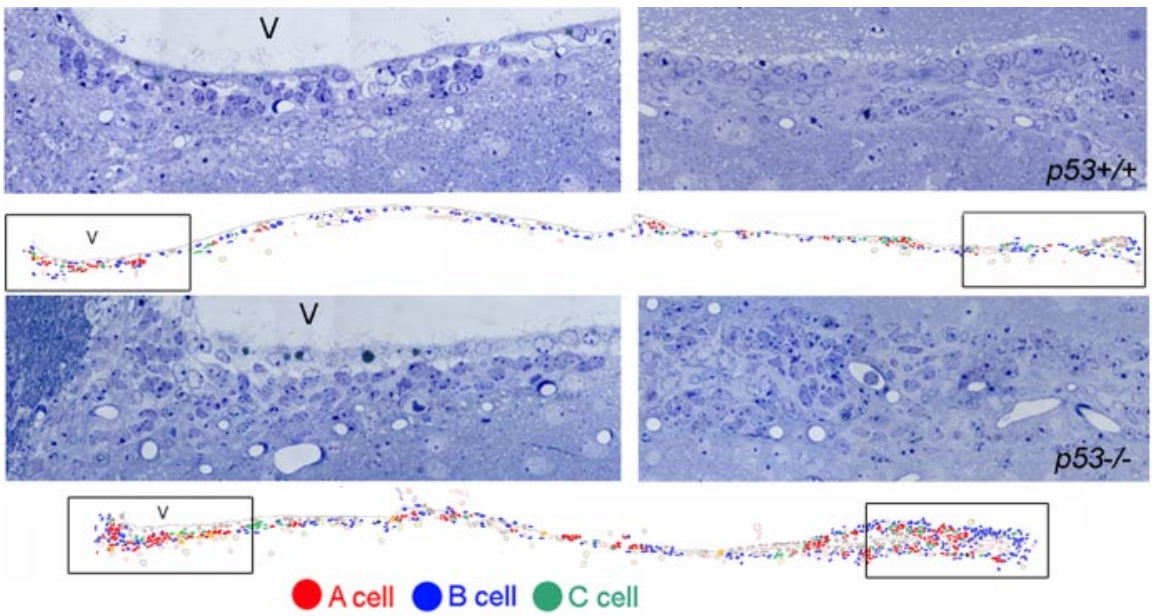

Figure 2. Topographic map showing the heterogeneous distribution of cell types in the wall of the lateral ventricles of $p 53^{-/-}$ mice compared with $p 53^{+/+}$. Topographic map of the SVZ determined by electron microscopy analysis and reconstruction of sequential sections. Each cell type is represented by a dot (red, A cells; blue, B cells; green, C cells; v, lateral ventricle); the ependymal cells lining the ventricular lumen are not shown. The boxed area corresponds to the adjacent enlarged semithin sections of the anterolateral superior corner and of the inferior border of the SVZ of $p 53^{+/+}$and $p 53^{-/-}$mice stained with toluidine blue ( $v$, lateral ventricle). Although some individual variability was observed in the length of the SVZ among different mice, no statistically significant difference was detected between the two genotypes.
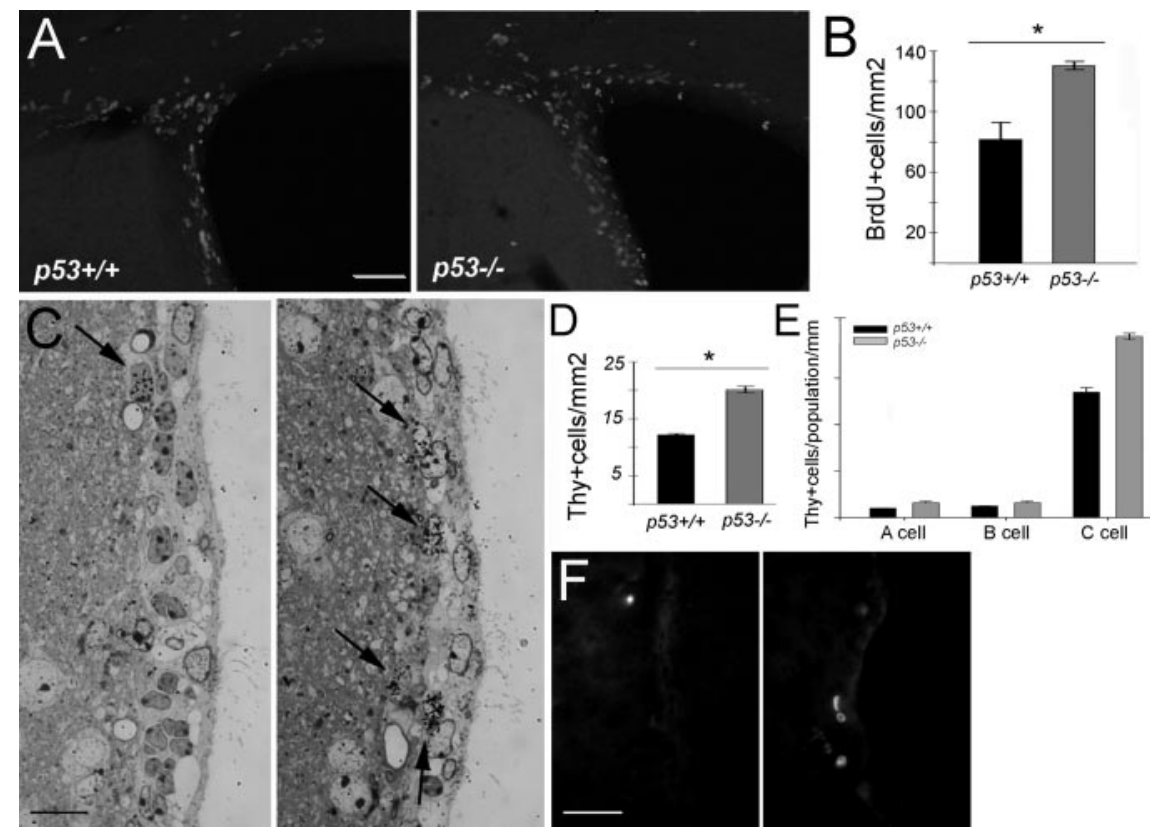

Figure 3. Loss of $p 53$ confers a proliferative advantage to fast-proliferating population and to quiescent type $B$ cells. $A$, Immunoreactive BrdU ${ }^{+}$cells detected in the anterior horn of the SVZ of $p 53^{+/+}$and $p 53^{-/-}$littermates after a $1 \mathrm{~h}$ pulse labeling. Scale bar, $120 \mu \mathrm{m}$. B, Bar graph representing the number of BrdU ${ }^{+}$cells per unit area in $p 53^{+/+}$(black bar) and $p 53^{-1-}$ (gray bar) mice. The asterisks indicate statistical significance, ${ }^{*} p<0.05$. C, Toluidine blue-stained semithin sections of proliferating cells (arrows) in the lateral wall of the ventricles after [ $\left.{ }^{3} \mathrm{H}\right] \mathrm{Thy}$ incorporation and autoradiography ( $\mathrm{V}$, ventricular lumen). Scale bar, $10 \mu \mathrm{m}$. D, Bar graph representing the total number of $\left[{ }^{3} \mathrm{H}\right]$ Thy cells per surface area in the SVZ of $p 53^{+/+}$ (black bar) and $p 53^{-\prime-}$ (gray bar) mice. The asterisks indicate statistically significant differences between the two groups, ${ }^{*} p<$ 0.05. $\boldsymbol{E}$, The bar graphs indicate the percentage of cells in S-phase in each subpopulation in the SVZ of $p 53^{+/+}$(black bar) and $p 53^{-1-}$ (gray bar) mice identified by electron microscopy. $\boldsymbol{F}$, Long-term retention of BrdU labeling of neural stem cells in the SVZ. Note the presence of a single cell in $p 53^{+/+}$and several cells in the $p 53^{-/-}$littermates (v, ventricular lumen). Scale bar, $25 \mu \mathrm{m}$.

Immunoreactive cells were analyzed using a fluorescence microscope (Leica, Heerbrugg, Switzerland), and images were captured using a Hamamatsu (Hamamatsu City, Japan) CCD camera interfaced with a G4 computer.

EM cell counts. Ultrathin $(60 \mathrm{~nm})$ sections were cut with a diamond knife, stained with lead citrate, and examined under a Jeol (Tokyo, Japan) 1010 TEM electron microscope. Type A cells, were identified by the small size, scanty cytoplasm, and fusiform appearance; type B cells were identified as large, less electron-dense cells, rich of intermediate filaments; type $\mathrm{C}$ cells were characterized by the presence of characteristically large nuclei and lack of intermediate filaments. The different cell types in the adult SVZ were counted in an oblique reverse orientation and expressed as percentage of total cell counts and also per unit length, as described previously (Doetsch et al., 1997). No difference was observed in the calculated mean length of the ventricular wall of SVZ of $p 53^{-/-}$and $p 53^{+/+}$mice. Graphical exploration of our data indicated that we could safely assume homogeneity of variance and normal distribution. Thus, we conducted a Student's $t$ test to analyze the differences in cell number in the SVZ. All reported probabilities were two tailed. Significance level for the rejection of the null hypothesis was set at $\alpha=0.05$

Neurosphere culture. SVZ cells were collected from $p 53^{+/+}$and $p 53^{-/-}$mice in Petri dishes containing PIPES buffer (in mM: 20 PIPES, 25 glucose, $120 \mathrm{NaCl}$, and $0.5 \mathrm{KCl}, \mathrm{pH}$ 7.4). After digestion with papain, cells were dissociated and resuspended in Neurobasal medium (Invitrogen) supplemented with B27 (Invitrogen), 2 mM L-glutamine (Invitrogen), antibiotic/antimycotic (Invitrogen), and $2 \mu \mathrm{g} / \mathrm{ml}$ heparin (Sigma). Equal number of cells were plated and kept in medium containing $20 \mathrm{ng} / \mathrm{ml}$ epidermal growth factor (EGF) and $10 \mathrm{ng} / \mathrm{ml}$ basic FGF. For the experiments performed at high density, the amount of plated cells was 10,000 cells $/ \mathrm{cm}^{2}$. For the experiments performed at low density, the amount of plated cells was $1000-2000$ cells/ $\mathrm{cm}^{2}$. The number of neurospheres was counted $7 \mathrm{~d}$ after plating. For the differentiation studies, the neurospheres were dissociated, and the cells were then plated in poly-ornithine-coated chamber slides without mitogens in the presence (or absence) of $2 \%$ FBS. The amplification rate was defined as $x=$ (number of viable cells in passage $N+1 /$ number of plated cells). Self renewal rate was calculated as $x=$ (number of neurospheres in passage $N+1 /$ number of plated cells) $\times 100$. Clonal self-renewal was calculated by transferring individual neurospheres of similar size into individual wells of a 48 -well plate and counting the total number of neurospheres generated after $5 \mathrm{~d}$.

Retroviral infection of adult SVZ cells. Neurospheres were mechanically dissociated and incubated with MSCV-NRasV12-IRES-GFP (a gift from Dr. James Downing, St Jude Children's Research Hospital, Memphis, TN) or MSCV-IRES-GFP empty vector ecotropic retroviruses in the presence of $8 \mu \mathrm{g} / \mathrm{ml}$ polybrene. Infection was allowed to proceed at $37^{\circ} \mathrm{C}$ under continuous shaking during the first $30 \mathrm{~min}$. The infected cells were then transferred to culture dishes and placed in the incubator for an additional $2 \mathrm{~h}$. Infection was terminated by adding fresh growth medium to the cultures. On the following day, cells were centrifuged and replated onto eight-well chamber slides in differentiation medium to assess their ability to differentiate. 
Adenoviral infection of SVZ cells. After dissociation of primary neurospheres, an equal number of cells $\left(5 \times 10^{4}\right)$ was resuspended in serumfree medium containing mitogens and $10^{6}$ viral particles of the adenovirus-CMV-Cre recombinase (Cre) (from Gene Transfer Vector Core, University of Iowa, Iowa City, IA) corresponding to a multiplicity of infection of 35 . The infection was performed in cells kept in suspension in a $15 \mathrm{ml}$ conical tube (Falcon; BD Biosciences, Bedford, MA) for $1 \mathrm{~h}$ at $37^{\circ} \mathrm{C}$ in the incubator. After collection by centrifugation, the supernatant containing the virus was discarded, and the cell pellet was resuspended in fresh medium. After a $2 \mathrm{~d}$ recovery period, the majority of the cells were grown in medium containing mitogens to assess neurosphere formation, whereas some cells were plated in slide chambers and cultured for $7 \mathrm{~d}$ in differentiation medium. After fixation, cultured cells were stained with antibodies against Cre or Tuj1 or were processed for terminal deoxynucleotidyl transferase-mediated biotinylated UTP nick end labeling (TUNEL) assay. The gene-transfer efficiency was $98 \pm 1.8 \%$, as calculated by dividing the number of $4^{\prime}, 6^{\prime}$-diamidino-2-phenylindole $(\mathrm{DAPI})^{+} / \mathrm{Cre}^{+}$cells by the total number of $\mathrm{DAPI}^{+}$cells.

\section{Results}

In physiological conditions, the levels of $p 53$ detected in the SVZ were very low (Fig. $1 A$ ), but they increased after brain irradiation, especially along the lateral walls of the ventricles (Fig. $1 B$ ). Loss of p53 induced detectable changes in this region, as a randomly distributed thickening of the cellular layer bordering the ventricles (Fig. 1C). Areas of cell density comparable with that of $p 53^{+/+}$littermates were observed within regions of hyperplasia (Fig. 1C). This overall effect on cell density was confirmed by cell counts that revealed $343.47 \pm 13.26$ cells $/ \mathrm{mm}$ in $p 53^{-/-}$mice (C57BL/6 Trp53; $n=5$ ) compared with $255.24 \pm 5.63$ cells $/ \mathrm{mm}$ in the SVZ of $p 53^{+/+}$littermates (C57BL/6; $\left.n=5\right)$. Because the SVZ is composed of distinct cellular subpopulations, we asked whether the effect of loss of $p 53$ was generalized or specific for distinct cell types. Quantification of the distinct cell types along the ventricular wall (Fig. $1 D)$ revealed a statistically significant increase of type A $(91.48 \pm 7.95)$ and type B $(94.2 \pm 9.6)$ cells in $p 53^{-/-}$mice $(n=5)$ compared with $p 53^{+/+}$littermates (type A, $65 \pm 3$ cells $/ \mathrm{mm}$; type $\mathrm{B}, 70.8 \pm 7.8$ cells $/ \mathrm{mm} ; n=5)$. In contrast, the number of ependymal cells lining the lumen of the ventricles (type E) and type $\mathrm{C}$ precursors was relatively constant $\left(p 53^{-/-}\right.$, $34.35 \pm 7.96$ cells $/ \mathrm{mm} ; p 53^{+/+}, 30.17 \pm 0.83 \mathrm{cells} / \mathrm{mm}$ ) (Fig. $1 D)$. In general, we observed an increase of $\mathrm{B}$ cells contacting the ventricle $\left(B_{v}\right)$, a feature of $B$ cell activation and lineage progression toward the type $C$, but their low number precluded any accurate statistical analysis. The selective increase of these cell types in the SVZ of $p 53^{-1-}$ mice was confirmed by immunohistochemistry, using antibodies against PSA-NCAM to identify A cells (see Fig. 5A) and against GFAP to identify B cells (data not shown). The excess A cells were detected along the walls of the lateral ventricle and especially at the anterolateral corner (Fig. 2A) (see Fig. 5), whereas the B cells were homogeneously distributed to the inferior border of the SVZ. The distribution of these areas of cellular hyperplasia corresponding to specific cell types was further confirmed by a camera lucida serial reconstruction. A diagram of the SVZ of $p 53^{+/+}$and $p 53^{-/-}$mice was drawn based on toluidine blue-stained semithin sections. Each cell type was identified in the corresponding ultrathin section, and its topographic location along the lateral wall of the ventricles was accurately recorded on the diagram, using a different color for each cell type (Fig. 2A). This pseudocolor map confirmed the distribution of the distinct cell types. Variability on the length of the SVZ was observed in distinct mice. However, a systematic measurement of the length of the lateral wall of the ventricles in six $p 53^{+/+}$and $p 53^{-/-}$mice did not reveal statistically significant

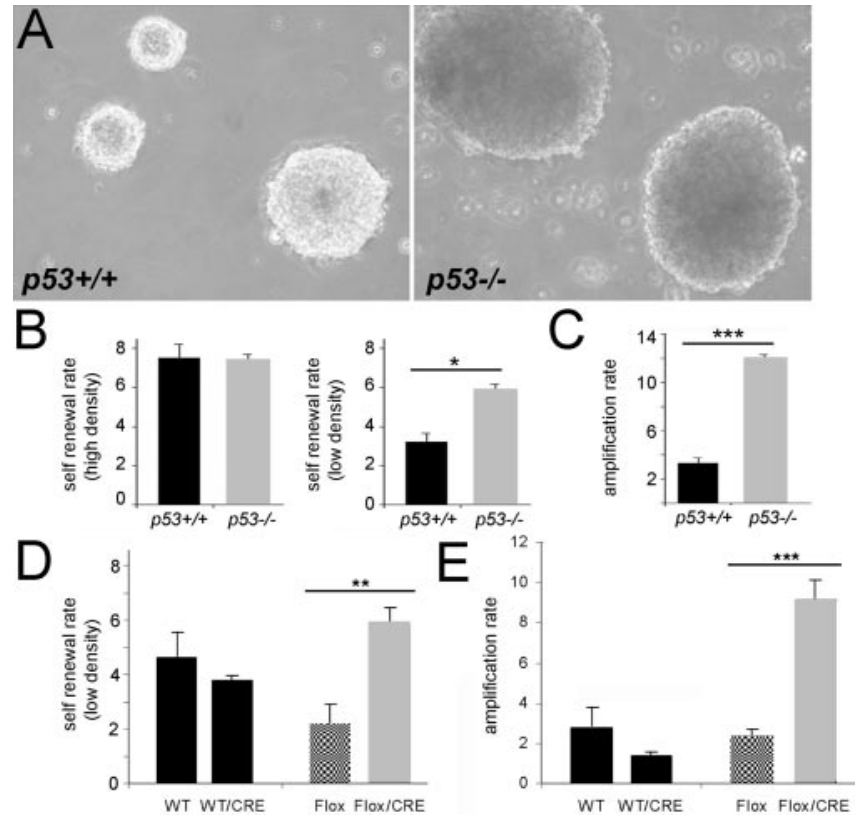

Figure 4. Effect of p53 loss-of-function on neurosphere-forming SVZ cells. A, Representative bright-field picture of secondary neurospheres generated from $p 53^{+/+}$and $p 53^{-/-}$mice. Note the larger size of the spheres in the $p 53^{-/-}$cultures. $\boldsymbol{B}$, Quantification of self-renewal in $p 53^{+/+}$and $p 53^{-/-}$high- and low-density cultures. ${ }^{*} p<0.05$. C, The amplification rate, measuring the total number of viable cells divided by the number of plated cells, was statistically higher in $p 53^{-/-}$mice; ${ }^{* * *} p<0.001$. D, Self-renewal rate in $p 53^{+/+}$and $p 53^{\text {flox/flox }}$ low-density cultures, either uninfected or infected with adenoviral vectors expressing $C r e$. The Cre-infected $p 53^{\text {flox/flox }}$ cultures formed a larger number of neurospheres than uninfected or Cre-infected $p 53^{+1+} . * * p<0.005$. E, The number of viable cells in $p 53^{f l o x}$ fflox cultures infected with adenoviral vectors expressing Cre recombinase was significantly higher than the number detected in Cre-infected $p 53^{+/+}$cells; ${ }^{* * *} p<0.001$. Note the remarkable similarity of the results obtained in the Cre-infected $p 53^{\text {flox flox }}$ and $p 53^{-1-}$ cultures. WT, Wild type.

differences between the two groups, because the length in $p 53^{+1+}$ mice was $1.66 \pm 0.12$ and in $p 53^{-/-}$mice was $1.56 \pm 0.04$.

Because the number of SVZ cells in each subpopulation is driven by a steady-state equilibrium between their birth and their death attributable to apoptosis or lineage progression, we systematically investigated the effects of $p 53$ loss-of-function on these properties in vivo and in vitro. Proliferation of SVZ cells was analyzed by assessing the number of cells in S-phase after $1 \mathrm{~h}$ in vivo labeling with BrdU followed by immunohistochemistry or titrated $\left[{ }^{3} \mathrm{H}\right]$ Thy followed by autoradiography (Fig. 3). The number of immunoreactive $\mathrm{BrdU}^{+}$cells in the anterior SVZ of $p 53^{-1-}$ mice $(x=127 \pm 3.66 ; n=3)$ was $62 \%$ higher than the number of $\mathrm{BrdU}^{+}$cells detected in equivalent regions of the SVZ of $p 53^{+/+}$animals $(x=77 \pm 1 ; n=3)$, and represented a statistically significant increase $(p<0.005)$ of cells in S-phase in $p 53^{-/-}$mice (Fig. 3B). The total number of $\left[{ }^{3} \mathrm{H}\right] \mathrm{Thy}^{+}$cells was counted in semithin sections after autoradiography (Fig. $3 C$ ) and confirmed the proliferative advantage conferred by the loss of $p 53$ $(x=20.64 \pm 0.39$ cells $/ \mathrm{mm} ; n=3)$ to SVZ cells (Fig. $3 D)$ compared with $p 53^{+/+}$littermates $(x=12.92 \pm 1.68$ cells $/ \mathrm{mm} ; p<$ $0.05)$. To define whether loss of $p 53$ equally affected proliferation of distinct cell types, the identity of the proliferating cells was defined by serial ultrastructural analysis of $\left[{ }^{3} \mathrm{H}\right] \mathrm{Thy}^{+}$sections. The number of $\left[{ }^{3} \mathrm{H}\right] \mathrm{Thy}^{+}$cells in each SVZ subpopulation was detected per unit of surface area and then normalized to the total number of cells in that population, to obtain the relative proportion of proliferating cells in each cell type (Fig. $3 E$ ). This analysis revealed a statistically significant increase of fast-proliferating $\mathrm{C}$ 


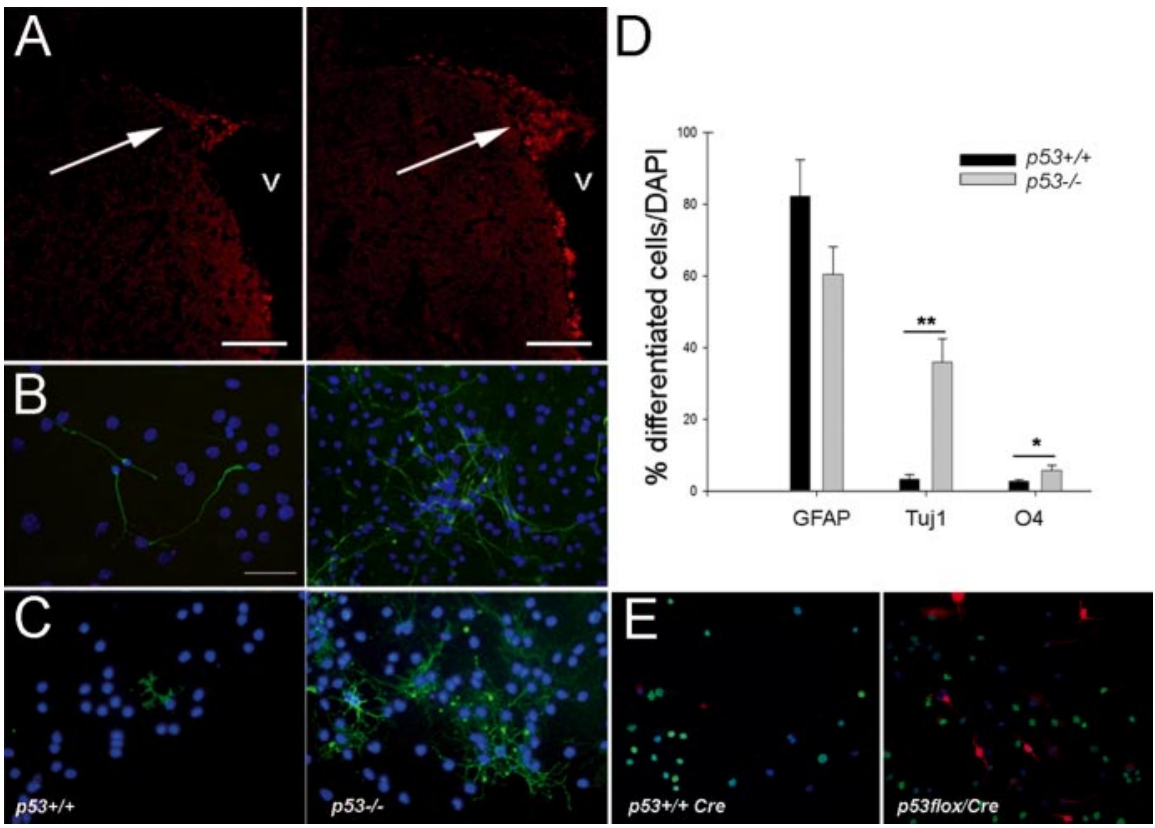

Figure 5. Loss of $p 53$ increases the number of neuroblasts both in vivo and in vitro. $\boldsymbol{A}$, Immunofluorescence of the anterolateral superior corner of the SVZ stained with antibodies against PSA-NCAM (red) to identify the presence of neuroblastic migratory A cells. Note the increased immunoreactivity in $p 53^{-/-}$mice. Scale bar, $250 \mu \mathrm{m}$. B, C, Immunocytochemistry of $p 53^{+1+}$ and $p 53^{-1-}$ SVZ cells differentiated for $7 \mathrm{~d}$ in vitro and stained with antibodies against the neuronal marker Tuj1 $(\boldsymbol{B})$ and the oligodendrocyte marker 04 (C). Note the increased number of TuJ1 ${ }^{+}$and $04^{+}$cells in $p 53^{-/-}$compared with the $p 53^{+/+}$ cultures. Scale bar, $180 \mu \mathrm{m}$. D, Quantification of the results illustrated in $\boldsymbol{B} .{ }^{*} p<0.05$; $^{* *} p<0.01$ ). $\boldsymbol{E}$, Immunocytochemistry of $p 53^{+/+}$and $p 53^{\text {flox/flox }}$ cultures, uninfected or infected with adenoviral vectors expressing (re recombinase and then differentiated for $7 \mathrm{~d}$ in vitro. Cultures were stained with antibodies against the neuronal marker Tuj1 (red) to detect neuroblasts and against Cre (green) to detect infected cells. Note the increased number of TuJ1 ${ }^{+}$cells in the Cre-infected $p 53^{\text {flox/flox }}$ cultures compared with $p 53^{+/+}$

cells in S-phase in $p 53^{-/-}$mice compared with $p 53^{+/+}$, whereas no difference was observed in proliferating A and B cells (Fig. $3 E$ ). These results suggest that the increase in specific SVZ subpopulations detected in $p 53^{-1-}$ mice could not be simply explained in terms of growth advantage provided by $p 53$ loss-of-function, but revealed a much more complex effect on the population dynamics.

Because astrocyte-like B cells are known to be relatively quiescent (Morshead et al., 1994), we asked whether p53 loss-offunction affected this slow-dividing cell population by performing long-term labeling experiments. Mice of both genotypes received a single injection of BrdU or $\left[{ }^{3} \mathrm{H}\right] \mathrm{Thy}^{+}$and were analyzed 2-4 weeks later. Of all of the cells incorporating the label at the time of injection, only the relatively quiescent ones retained the label after several weeks, whereas those fast-proliferating lost the label by dilution after several rounds of division. The detection of label-retaining cells in the SVZ was consistently higher in $p 53^{-1-}$ mice compared with $p 53^{+/+}$(Fig. $3 F$ ), although the low number precluded accurate statistical analysis. Thus, loss of $p 53$ increased the division of the relatively quiescent astrocyte-like B cells, without significantly modifying their slow rate of proliferation.

Because a characteristic feature of SVZ cells is self-renewal, we asked whether the increased number of B cells in $p 53^{-/}$mice could be attributed to an enhancement of this property. It is well accepted that the property of self-renewal can be assessed in vitro (Reynolds and Weiss, 1992; Morshead et al., 1994; Parker et al., 2005; Reynolds and Rietze, 2005) and is measured by the ability to form neurospheres (Fig. 4A). However, this assay cannot be used as the only criterion of analysis of stem cell behavior (Parker et al., 2005; Reynolds and Rietze, 2005). Thus, SVZ cells were isolated from $p 53^{-/-}$and $p 53^{+/+}$mice plated at high or low density and the total number of neurospheres counted after $7 \mathrm{~d}$ (Fig. $4 B$ ). The effect of $p 53$ loss-of-function on the number of neurospheres was dependent on cell density. At high density, the number of neurospheres was similar in the two groups, whereas at low density, the $p 53^{-1-}$ cultures had $70 \%$ more neurospheres than $p 53^{+/+}$cultures (Fig. $4 B$ ). Besides the increased number of spheres, we consistently noticed that the size of the $p 53^{-1-}$ neurospheres was significantly larger than $p 53^{+1+}$ (Fig. $4 A$ ). The increase in size was associated with a large increase in amplification rate (i.e., the number of viable cells detected after $7 \mathrm{~d}$ in culture) (Fig. 4C). To address whether the observed effects of $p 53$ loss-of-function were cell autonomous or consequent to a compensatory mechanism, we repeated the experiments on cells isolated from the SVZ of $p 53^{\text {flox/flox }}$ (Marino et al., 2000) and $p 53^{+1+}$ mice. The excision of $p 53$ was achieved by infecting the $p 53^{\text {flox/flox }}$ cultures with adenoviral vectors expressing Cre (Fig. 4D,E). Wild-type cultures also received Cre infection as an additional control. After a $2 \mathrm{~d}$ recovery period, the cells were fixed, and infection efficiency was calculated to be $98 \pm 1.8 \%$ (data not shown). Given the high level of transfection efficiency, we performed additional experiments addressing the effect of $p 53$ excision by Cre on selfrenewal and proliferation. Cre infection of $p 53^{+/+}$cultures behaved as wild type not transduced control, generating a similar number of neurospheres as Cre-infected $p 53^{+/+}$cultures (Fig. $4 D$ ). We also observed the predicted increase in the number of neurospheres generated from Cre-infected $p 53^{\text {flox/flox }}$ cultures compared with controls (Fig. 4D). Thus, we concluded that the effect of $p 53$ on self-renewal is attributable to a direct effect of $p 53$ on the adult SVZ cells rather than to a compensatory effect. Because $p 53$ loss-of-function also increased the amplification rate compared with $p 53^{+/+}$mice (Fig. $4 C$ ), we asked whether a similar effect could be observed in Cre-infected $p 53^{\text {flox/flox }}$ cultures compared with controls. For this reason, we compared the total number of viable cells in Cre-infected $p 53^{+/+}$and $p 53^{\text {flox/flox }}$ cultures (Fig. $4 E$ ). The results were remarkably similar to those reported previously for the $p 53^{-/-}$cultures. Therefore, these results strongly argue in favor of a direct, rather than compensatory, effect of $p 53$ loss-of-function on the regulation of self-renewal and proliferation of adult SVZ pluripotent progenitors.

It remained to be explained, however, why the increase of slow-proliferating $\mathrm{B}$ cells and fast-proliferating $\mathrm{C}$ cells detected in $p 53^{-1-}$ mice was not associated with the expansion of the $\mathrm{C}$ cell compartment. A possible explanation for the lack of accumulation of $\mathrm{C}$ cells in vivo was their rapid differentiation toward the generation of A cells or oligodendrocytes. This hypothesis was supported by the significant increase of A cells detected in $p 53^{-/-}$ mice (Fig. 5A) and the increased number of $\mathrm{CC}^{+}$oligodendrocytes observed in vivo (data not shown). Thus, in the absence of p53, SVZ cells proliferated more but retained the ability to 
differentiate along distinct lineages. Experiments conducted in vitro, in neurospheres generated from $p 53^{-/-}$and $p 53^{+/+}$mice and allowed to spontaneously differentiate into neurons or glial cells, supported this interpretation (Fig. $5 B, C)$. In $p 53^{+/+}$mice, $82.13 \pm 10.29 \%$ of cells were $\mathrm{GFAP}^{+}, 3.22 \pm 1.28 \%$ of cells were $\mathrm{TuJ} 1^{+}$, and $2.66 \pm 0.42 \%$ were $\mathrm{O}^{+}{ }^{+}$. In contrast, in $p 53^{-/-}$mice, $60.39 \pm$ $7.64 \%$ of cells were $\mathrm{GFAP}^{+}, 35.85 \pm$ $6.61 \%$ of cells were $\mathrm{TuJ}^{+}$, and $5.63 \pm 1.51 \%$ were $\mathrm{O}^{+}$(Fig. $5 D$ ). Thus, the significantly higher number of neuroblasts (11-fold) and oligodendrocytes (2fold) generated by $p 53^{-/-}$neurospheres SVZ cells in vitro was consistent with the increased number of differentiated cells detected in $p 53^{-1-}$ mice. Higher number of neurons were also observed in cultures derived from Cre-infected $p 53^{\text {flox/flox }}$ mice compared with uninfected $p 53^{\text {flox/flox }}$ and Cre-infected $p 53^{+/+}$cultures, thus indicating also that the effect of $p 53$ on neurogenesis was direct and not consequent to the activation of compensatory mechanisms.

An alternative explanation for the lack of $C$ cell accumulation in $p 53^{-/-}$mice was an increase in $p 53$-independent apoptosis. In contrast with the well established role of $p 53$, we consistently observed an increased number of TUNEL ${ }^{+}$cells in the SVZ of $p 53^{-/-}$mice localized to those areas of increased cell density (Fig. 6A) and possibly resulting from compensatory death. The greater number of spontaneously dying cells in $p 53^{-/-}$cultures $(x=5 \pm 0.7 \%)$ compared with controls $(x=1.2 \pm 0.6 \%)$ was also detected in vitro (Fig. $6 B$ ). Increased apoptosis, however, was not observed in Cre-infected $p 53^{\text {flox/flox }}$ mice compared with uninfected $p 53^{\text {flox/flox }}$ and Cre-infected $p 53^{+/+}$cultures, thus supporting the interpretation of a compensatory $p 53$-independent apoptosis in the $p 53^{-1-}$ mice. Together, these data suggest a critical role for $p 53$ in regulating the number of adult SVZ cells by directly modulating proliferation, differentiation, and self-renewal or survival, whereas the compensatory increase of $p 53$-independent death is consistent with the lack of spontaneous glial tumors in $p 53^{-/-}$mice.

It is important to mention, however, that loss of $p 53$ results in a $60 \%$ incidence of glioblastoma-like tumors in $p 53^{-1-}$ mice, but not in $p 53^{+/-}$or in $p 53^{+/+}$littermates, after prenatal exposure to the mutagen ENU (Oda et al., 1997; Leonard et al., 2001). These tumors were typically localized in periventricular locations, at the border between the SVZ and the corpus callosum (Fig. $7 A, B$ ) or between the SVZ and the striatum. The tumoral masses were often spherical and not capsulated with clear signs of parenchymal infiltration. Neovascularization was frequently detected and
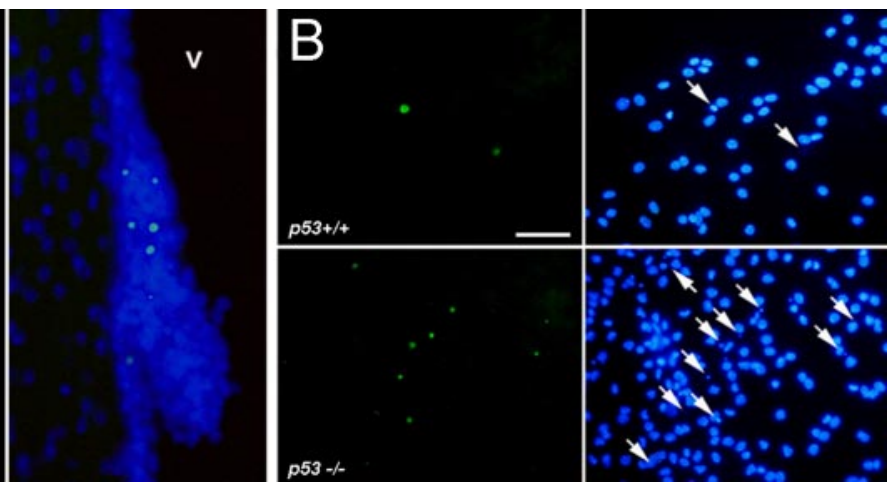

Figure 6. Spontaneous apoptosis is increased in the hyperplastic areas of the $p 53^{-/-}$SVZ.A, TUNEL assay in vivo in the SVZ of $p 53^{-1-}$ mice, showing the presence of several apoptotic cells (green nuclei) within areas of localized hyperplasia (blue indicates DAPI as nuclear counterstain). $\boldsymbol{B}$, TUNEL assay in vitro in cells dissociated from $p 53^{+/+}$and $p 53^{-/-}$secondary neurospheres. Apoptotic nuclei are identified by arrows (TUNEL ${ }^{+}$, green; DAPI, blue as nuclear counterstain). Scale bar, $180 \mu \mathrm{m}$.
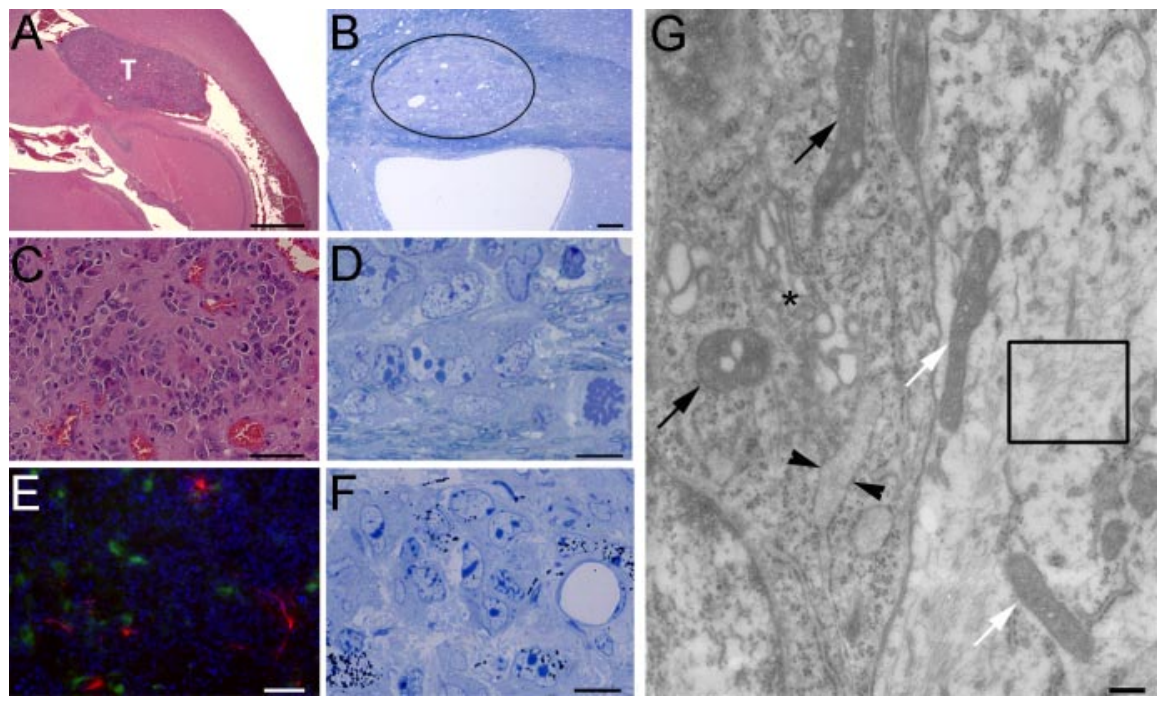

Figure 7. Glioblastoma-like tumors are detected in periventricular locations in adult $p 53^{-/-}$mice that have been exposed to the mutagen ENU. $\boldsymbol{A}$, Micrograph of a sagittal section stained with hematoxylin-eosin showing a large tumoral mass (T) in periventricular location. Scale bar, $500 \mu \mathrm{m}$. B, Semithin section stained with toluidine blue showing a tumoral mass invading the corpus callosum and displacing the myelinated axons (circle). Scale bar, $75 \mu \mathrm{m}$. C, High-magnification view of the tumor, showing anaplastic cells, extensive microvascularization, and hemorrhages typical of glioblastomas. Scale bar, $50 \mu \mathrm{m}$. $\boldsymbol{D}$, Very pleomorphic and anaplastic cells with dark cytoplasm, giant and invaginated nuclei with numerous chromatin clusters, and enormous nucleoli. Scale bar, $10 \mu \mathrm{m}$. $\boldsymbol{E}$, Immunohistochemical analysis of the tumoral mass showing the presence of nestin ${ }^{+}$(green) and $\mathrm{GFAP}^{+}$(red) cells. DAPI ${ }^{+}$(blue) was used as nuclear counterstain. Scale bar, $200 \mu \mathrm{m}$. F, Increased thymidine incorporation (after $1 \mathrm{~h}$ injection) is observed in cells within the tumor and more prominently at the periphery. Scale bar, $10 \mu \mathrm{m}$. $\mathbf{G}$, Ultrastructural detail of a tumoral cell (left) contacting a nontumoral astrocyte (right). Note the moderately electron-dense cytoplasm of the tumoral cell (left) compared with the normal astrocyte and the lack of intermediate filaments (rectangle). The tumoral cell is also characterized by the presence of vacuoles in the mitochondria (black arrows) compared with normal cells (white arrows), enlarged Golgi apparatus (black asterisk) compared with control (white asterisk), and abundant and dilated endoplasmic reticulum (arrowheads). Scale bar, $200 \mathrm{~nm}$.

associated with microhemorrhages and small necrotic areas (Fig. 7C), consistent with the histological features of glioblastoma-like tumors. In semithin sections obtained from tumoral masses, several aberrant mitotic figures were detected together with atypical giant cells (Fig. 7D). At the immunohistochemical level, the tumor was highly heterogeneous, with scattered distribution of GFAP- and nestin-immunoreactive cells (Fig. 7E). Proliferating cells were observed within the tumoral mass and more prominently at its periphery (Fig. $7 F$ ). At the ultrastructural level, tumoral cells were characterized by electron-dense cytoplasm, the absence of intermediate filaments and microtubules, an 


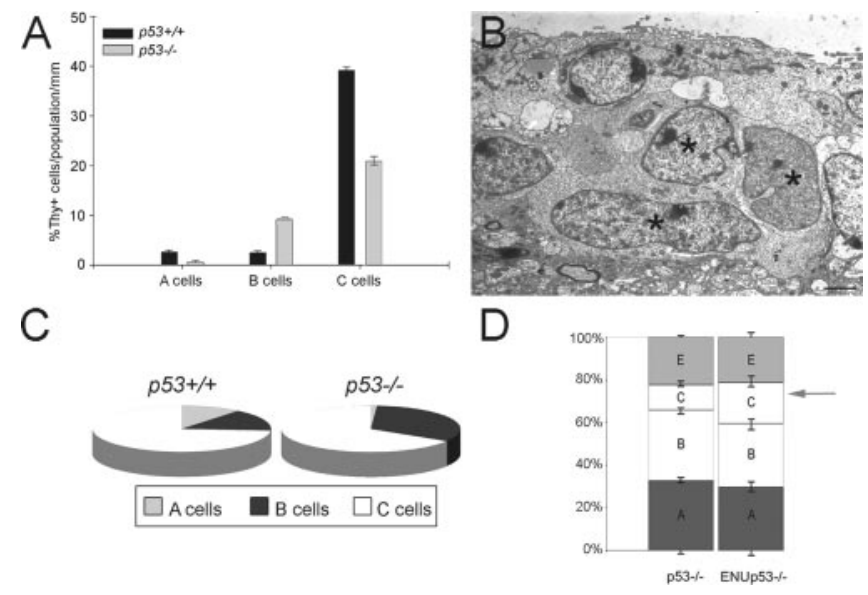

Figure 8. Prenatal exposure of $p 53^{-/-}$mice to ENU induces the formation of periventricular glioblastoma-like tumors and is associated with the recruitment of the quiescent type B cells to the fast-proliferating compartment. $A$, Bar graph representing the number of $\left[{ }^{3} \mathrm{H}\right]$ Thy ${ }^{+}$cells per unit area in each population of SVZ cells in untreated (gray) and ENU-treated (black) $p 53^{-1-}$ mice. These data indicate that, during ENU treatment, the relative proportions of proliferating $C$ and $A$ cells are decreased, whereas the proportion of proliferating $B$ cells is increased. $\boldsymbol{B}$, Ultrastructural appearance of activated C cells (asterisks) in ENU-treated $p 53^{-1-}$ mice. Note the presence of two C cells with giant nuclei and dispersed chromatin (left) and one cell with condensed chromatin (right, arrow), likely representing a B cell in transition. Ultrastructurally, C cells are characterized by the presence of large nuclei with invaginations and several nucleoli, a cytoplasm with abundant ribosomes, few mitochondria, endoplasmic reticulum cisternae, and a small Golgi apparatus. Scale bar, $2 \mu \mathrm{m}$. Although in physiological conditions the C cells are found in association with A cells, in ENU-treated $p 53^{-/-}$mice the C cells do not give rise to $A$ cells but continue to divide and form these aggregates. $C$, The pies indicate the relative contribution of each subpopulation of SVZ cells to the total number of proliferating $\left[{ }^{3} \mathrm{H}\right] \mathrm{Thy}{ }^{+}$within after a $1 \mathrm{~h}$ labeling period. Note the greater proportion of $\mathrm{B}$ cells in $\mathrm{S}$-phase in the ENU-treated $p 53^{-/-}$mice. $\boldsymbol{D}$, Relative shift of population dynamics before transformation. There is an accumulation of cells with intermediate feature between type $B$ and $C$ cells, with an expansion of the $B / C$ compartment (arrow) at the expenses of the more differentiated neuroblasts.

irregularly dilated endoplasmic reticulum, enlarged Golgi apparatus, and mitochondria with vacuoles or vesicles (Fig. 7E).

To identify the changes in population dynamics leading to tumor formation, we further quantified $\left[{ }^{3} \mathrm{H}\right] \mathrm{Thy}^{+}$incorporation in semithin sections from ENU-treated $p 53^{-/-}$mice (that develop spontaneous glioblastoma-like tumors) and compared these changes with those occurring in untreated $p 53^{-/-}$mice and in ENU-treated $p 53^{+/-}$mice (that do not develop these tumors). The identity of the labeled cells was assessed and quantified in serial sections from mice of different genotypes. The relative proportion of $\left[{ }^{3} \mathrm{H}\right] \mathrm{Thy}^{+} \mathrm{B}$ cells in the SVZ was increased in ENUtreated $p 53^{-/-}$mice compared with untreated $p 53^{-/-}$mice, whereas the relative proportion of type $\mathrm{A}$ and $\mathrm{C}$ cells in S-phase was decreased (Fig. 8A). Because the number of $\left[{ }^{3} \mathrm{H}\right]$ Thy ${ }^{+}$cells identified after a $1 \mathrm{~h}$ labeling pulse reflects the number of cells in $S$-phase within a relatively short time, the greater proportion of relatively quiescent $\left[{ }^{3} \mathrm{H}\right] \mathrm{Thy}^{+}$type $\mathrm{B}$ cells identified in the ENUtreated $p 53^{--}$mice suggested the recruitment of these cells into the fast proliferative compartment. This interpretation was supported by the detection of several cells with "immature" features, a transition stage between type $\mathrm{B}$ and $\mathrm{C}$ cells (Fig. $8 B$ ). Together, these data indicate that the neoplastic transformation of SVZ cells in adult $p 53^{-/-}$mice after prenatal exposure to ENU is preceded by important changes of the SVZ population dynamics, including the recruitment of $\mathrm{B}$ cells to the fast-proliferating compartment (Fig. $8 C$ ) and the accumulation of undifferentiated cells with intermediate characteristics between types B and C (Fig. 8D), which cannot progress toward the neuronal or glial cell lineage.
To verify the cell-autonomous nature of these effects and define the changes leading to neoplastic transformation, we isolated cells from the SVZ of ENU-treated $p 53^{-1-}$ (that develop glioblastoma-like tumors) and $p 53^{+/-}$mice (that do not develop glioblastoma-like tumors) and compared their behavior. One possibility was that ENU treatment modified the property of selfrenewal. We therefore assessed clonal self-renewal (i.e., the ability of each neurosphere to generate clonal aggregates) in SVZ cells in isolated ENU-treated and untreated $p 53^{---}$and $p 53^{+/-}$mice. Clonal self-renewal was rapidly exhausted after three serial passages of neurospheres from ENU-treated $p 53^{+/-}$and from untreated $p 53^{-/-}$and $p 53^{+/-}$mice, thus indicating that these cells were likely fast-proliferating multipotential progenitors (Fig. $9 A)$. In contrast, ENU-treated $p 53^{-1-}$-derived neurospheres retained the ability to self-renew even after three passages (Fig. 9A) and were characterized by a very large size (Fig. $9 B$ ). Thus, the proliferative advantage conferred by loss of $p 53$ associated with the enhanced self-renewal induced by ENU exposure modified these properties of adult neural stem cells only in those animals with a high incidence to develop glioblastoma-like tumors.

Another possibility accounting for the abundant presence of immature cells in vivo in ENU-treated $p 53^{-/-}$mice was that ENU treatment modified the ability of adult multipotential SVZ progenitors to differentiate along distinct lineages. We therefore assessed differentiation of neurospheres from ENU-treated and untreated $p 53^{-/-}$and $p 53^{+/-}$mice by immunocytochemistry using antibodies against the cellular markers TuJ1, GFAP, O4, and nestin (Fig. 9C-F). Differentiation proceeded normally in cultures from ENU-treated $p 53^{+/-}$and untreated $p 53^{-/-}$or $p 53^{+/-}$mice, in agreement with the absence of spontaneous tumors. In contrast, the cells isolated from the ENU-treated $p 53^{-/-}$ mice did not differentiate along the distinct lineages and retained very immature features, including simple bipolar or unipolar morphology and nestin immunoreactivity (Fig. 9E). Some cells were both nestin ${ }^{+}$and $\mathrm{GFAP}^{+}$immunoreactive and showed the tendency to grow as cellular aggregates (Fig. $9 F$ ). Other cells were $\mathrm{GFAP}^{+}$but with long and bulky processes rather than with the typical flat morphology of cells adhering to the substrate (Fig. $9 F)$. These changes of antigenic properties and morphological appearance resembled those detected in tumoral masses in vivo and were also observed in SVZ cells from $p 53^{-1-}$ mice overexpressing the active form of Ras. Although the infection with the viral vector alone did not alter the properties of $p 53^{-/-}$cells (Fig. $9 G, H)$, the overexpression of constitutively active Ras induced a transformed phenotype on these cells, characterized by the persistence of nestin immunoreactivity, growth in aggregates, and immature morphology characterized by bulky processes and small soma (Fig. $9 H-J$ ).

\section{Discussion}

This paper addresses the important question of the neoplastic potential of adult SVZ cells. More specifically, it defines how loss of the tumor-suppressor gene $p 53$ modifies the cellular properties of distinct populations of cells in the adult SVZ, changes the dynamics between them, and leads to neoplastic transformation.

The role of neural stem cells and multipotential progenitors as cell-of-origin of glioblastoma has been suggested by the detection of positive immunoreactivity for immature markers such as nestin in human tumors (Dahlstrand et al., 1992; Toda et al., 2001; Ignatova et al., 2002; Bouvier et al., 2003) and by studies in transgenic mice overexpressing activated Ras and Akt in nestin ${ }^{+}$cells (Holland, 2000). Because loss of $p 53$ is detected early in glial brain tumors (von Deimling et al., 1992; Watanabe et al., 1996; Hayashi 

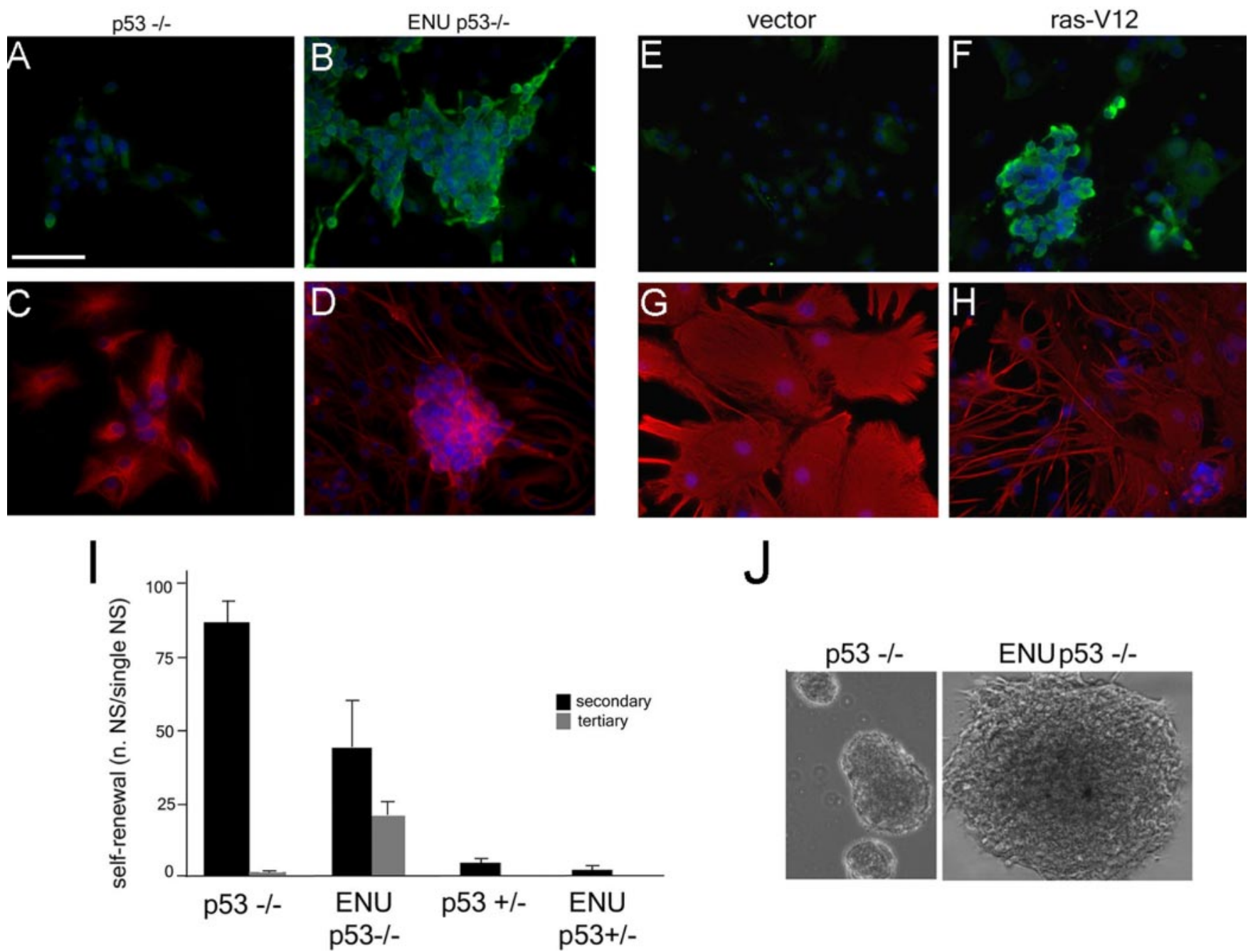

p53 -/-
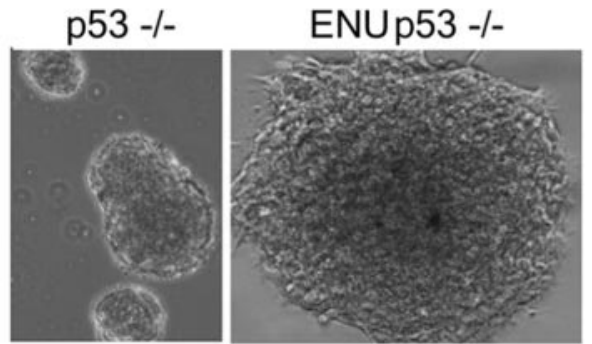

Figure 9. SVZ cells cultured from ENU-treated $p 53^{-/-}$mice show enhanced self-renewal and impaired differentiation properties. $\boldsymbol{A}$, Clonal self-renewal in mice of the indicated genotype that were exposed to the carcinogen ENU during the prenatal life. The bar graph indicates the average number of spheres generated by the dissociation of a single sphere after the second (black) or third (gray) passage. $\boldsymbol{B}$, Note the large size of the ENU-treated $p 53^{-/-}$sphere even after repeated passaging. $\boldsymbol{C}-\boldsymbol{F}$, Nestin (green in $\left.\boldsymbol{C}, \boldsymbol{E}\right), \mathrm{GFAP}($ red in $\boldsymbol{D}, \boldsymbol{F})$, and DAPI (blue in $\boldsymbol{C}-\boldsymbol{F}$ ) immunofluorescence indicating the persistence of large aggregates of immature nestin ${ }^{+}$cells and abnormal GFAP ${ }^{+}$cells in cultures from ENU-treated $p 53^{-/-}$mice $(\boldsymbol{F})$. G-J, Nestin (green in $\mathbf{G}-\boldsymbol{I}$ ) and GFAP (red in $\boldsymbol{H} \boldsymbol{J}$ ) immunofluorescence reveals similar aggregates of nestin ${ }^{+}$cells $(\boldsymbol{I})$ and astrocytes displaying aberrant morphology (red in $\boldsymbol{J}$ ) only in $p 53^{-/-}$cells expressing constitutively active Ras (Ras*). Scale bar, $75 \mu \mathrm{m}$.

et al., 2004), its mutation is observed in sphere-forming cells isolated from human glioblastoma (Ignatova et al., 2002) and its expression in the adult brain is confined to germinal areas (van Lookeren Campagne and Gill, 1998), we postulated that characterization of the changes induced by loss of $p 53$ in cells of the adult SVZ could lead us to a better understanding of the genesis of glial tumors.

Loss of $p 53$ does not induce spontaneous glial tumors (Donehower et al., 1992; Philipp-Staheli et al., 2004). However, we show here that it induces the formation of periventricular areas of cellular hyperplasia in the adult SVZ, characterized by clusters of $\mathrm{GFAP}^{+}$stem cells, mature glia, and neuroblasts (supplemental Fig. 1, available at www.jneurosci.org as supplemental material). These regions are highly reminiscent of the "microtumors" around the ventricles that were originally described at the early stages of glioma formation in rats prenatally exposed to mutagens (Lantos and Pilkington, 1979). They also resemble the previously described hyperplastic areas observed after intraventricular grafting of astrocytes-like stem cells (Zheng et al., 2002). The increased number of cells in the SVZ of $p 53^{-1-}$ mice is not attributable to decreased apoptosis, as predicted by the well known proapoptotic function of $p 53$ (D'Sa-Eipper et al., 2001; Leonard et al., 2001; Katayama et al., 2005). Our results clearly indicate an increase in compensatory apoptosis in $p 53^{-/-}$mice. Apoptotic cells were detected in vivo in those areas exhibiting the most dramatic hyperplastic changes and were likely attributable to upregulation of proapoptotic genes by other $p 53$ family members (S. Gil-Perotin and P. Casaccia-Bonnefil, unpublished observation). We show here that the increased cell number observed in the SVZ of $p 53^{-/-}$mice is consequent to the expansion of the stem cell/ progenitor compartment associated with their rapid differentiation toward the neuronal and glial lineages. Thus, loss of $p 53$ confers a proliferative advantage to the slow- and fastproliferating population of cells in the adult SVZ and favors the progression toward a differentiated phenotype. The balance between generation of extra SVZ cells and their elimination by apoptosis and differentiation accounts for the lack of spontaneous glial tumors in $p 53^{-/-}$mice (Donehower et al., 1992; PhilippStaheli et al., 2004).

Prenatal exposure of $p 53^{-1-}$ mice to ENU provides a DNA-damaging stimulus that leads to the formation of 
glioblastoma-like tumor in the adult SVZ (Leonard et al., 2001; Katayama et al., 2005). We show here that the transformed phenotype in ENU-treated $p 53^{-/-}$mice is the consequence of enhanced self-renewal and faster cell division of the relatively quiescent population, associated with expansion and impaired differentiation of multipotential progenitors. Similar effects are observed in vitro in $p 53^{-/-}$cells overexpressing a constitutively active form of Ras.

Therefore, transformation of adult SVZ cells is preceded by the recruitment of the quiescent self-renewing population to the fast-proliferating compartment and their inability to differentiate along distinct lineages. There are several potential explanations for the induced neoplastic changes in the SVZ of $p 53^{-/-}$ mice prenatally exposed to ENU. One possibility is that ENU, a potent alkylating agent, induces random mutations in the genome of SVZ cells, and this may affect the function or levels of molecules modulating their behavior. In support of this model is the concept that the susceptibility to develop cancer is dependent on the age of exposure and is directly correlated with the mutagenic effect of ENU (Slikker et al., 2004). Prenatal exposure has been shown to result in a sixfold higher frequency of mutation than adult exposure to the same agent (Slikker et al., 2004). An alternative possibility is that the maturation state of the SVZ cell may result in a differential susceptibility to apoptotic stimuli (Lee et al., 2001) and therefore affect the apoptotic response to mutagenic stimuli (Leonard et al., 2001). Finally, although we hypothesize that neoplastic transformation is a cell-autonomous event triggered by p53 loss of function, we cannot exclude the possibility that it may also result from autocrine or paracrine mechanisms. It is clear, however, from our data and from the literature that neoplastic transformation requires the synergism between p53 loss of function and additional stimuli.

The concept that glioblastoma formation involves the synergism between distinct pathways is supported by several other studies demonstrating tumor formation in $p 53^{-/-}$mice after increased PDGF signaling (Hesselager et al., 2003), prenatal exposure to ENU (Oda et al., 1997; Leonard et al., 2001), or Ras activation (Reilly et al., 2000).

It is important to mention, however, that this cellular mechanism leading to glial tumor formation is specific for SVZ cells and does not apply to other cell types. For example, loss of $p 53$ does not synergize with the constitutive activation of EGF receptor (EGFR) in astrocytes, although these cells have the ability to generate gliomas when expression of constitutively active EGFR is associated with loss of other cell cycle genes such as Ink $4 a$ and $\operatorname{Arf}$ (Bachoo et al., 2002). It is also worth mentioning that Ink4al Arf mutations have been also very recently detected in cells isolated from ENU-injected animals (Savarese et al., 2005). Together, these results indicate the existence of at least two mechanisms leading to the genesis of glioblastomas: one that is Ink4a/Arf dependent and $p 53$ independent and another one that is $p 53$ dependent. This explanation is in agreement with several studies in human gliomas reporting that $p 53$ and Inka/Arf mutations or EGFR amplification are mutually exclusive (Sung et al., 2000; Di Sapio et al., 2002). It is also supported by the evidence that EGFR amplification has been frequently observed in association with mutations or deletions of $\operatorname{Ink} 4 a / \operatorname{Arf}$ (Costello et al., 1996) but not in association with $p 53$ mutations (von Deimling et al., 1995).

In conclusion, our data indicate that loss of $p 53$ differentially affects the properties of distinct populations of adult SVZ cells by providing a proliferative advantage to slow- and fast-cycling cells. Transformation occurs when multiple converging pathways modulating the cell cycle kinetics cooperatively interact with other pathways affecting the differentiative potential of SVZ cells.

\section{References}

Alvarez-Buylla A, Lim DA (2004) For the long run: maintaining germinal niches in the adult brain. Neuron 41:683-686.

Bachoo RM, Maher EA, Ligon KL, Sharpless NE, Chan SS, You MJ, Tang Y, DeFrances J, Stover E, Weissleder R, Rowitch DH, Louis DN, DePinho RA (2002) Epidermal growth factor receptor and Ink4a/Arf: convergent mechanisms governing terminal differentiation and transformation along the neural stem cell to astrocyte axis. Cancer Cell 1:269-277.

Berger F, Gay E, Pelletier L, Tropel P, Wion D (2004) Development of gliomas: potential role of asymmetrical cell division of neural stem cells. Lancet Oncol 5:511-514.

Bouvier C, Bartoli C, Aguirre-Cruz L, Virard I, Colin C, Fernandez C, Gouvernet J, Figarella-Branger D (2003) Shared oligodendrocyte lineage gene expression in gliomas and oligodendrocyte progenitor cells. J Neurosurg 99:344-350.

Chow BM, Li YQ, Wong CS (2000) Radiation-induced apoptosis in the adult central nervous system is p53-dependent. Cell Death Differ 7:712-720.

Costello JF, Berger MS, Huang HS, Cavenee WK (1996) Silencing of p16/ CDKN2 expression in human gliomas by methylation and chromatin condensation. Cancer Res 56:2405-2410.

Dahlstrand J, Collins VP, Lendahl U (1992) Expression of the class VI intermediate filament nestin in human central nervous system tumors. Cancer Res 52:5334-5341.

Di Sapio A, Morra I, Pradotto L, Guido M, Schiffer D, Mauro A (2002) Molecular genetic changes in a series of neuroepithelial tumors of childhood. J Neurooncol 59:117-122.

Doetsch F, Garcia-Verdugo JM, Alvarez-Buylla A (1997) Cellular composition and three-dimensional organization of the subventricular germinal zone in the adult mammalian brain. J Neurosci 17:5046-5061.

Doetsch F, Caille I, Lim DA, Garcia-Verdugo JM, Alvarez-Buylla A (1999a) Subventricular zone astrocytes are neural stem cells in the adult mammalian brain. Cell 97:703-716.

Doetsch F, Garcia-Verdugo JM, Alvarez-Buylla A (1999b) Regeneration of a germinal layer in the adult mammalian brain. Proc Natl Acad Sci USA 96:11619-11624.

Doetsch F, Petreanu L, Caille I, Garcia-Verdugo JM, Alvarez-Buylla A (2002a) EGF converts transit-amplifying neurogenic precursors in the adult brain into multipotent stem cells. Neuron 36:1021-1034.

Doetsch F, Verdugo JM, Caille I, Alvarez-Buylla A, Chao MV, CasacciaBonnefil P (2002b) Lack of the cell-cycle inhibitor p27Kip1 results in selective increase of transit-amplifying cells for adult neurogenesis. J Neurosci 22:2255-2264.

Donehower LA, Harvey M, Slagle BL, McArthur MJ, Montgomery Jr CA, Butel JS, Bradley A (1992) Mice deficient for p53 are developmentally normal but susceptible to spontaneous tumours. Nature 356:215-221.

D'Sa-Eipper C, Leonard JR, Putcha G, Zheng TS, Flavell RA, Rakic P, Kuida K, Roth K (2001) DNA damage-induced neural precursor cell apoptosis requires $p 53$ and caspase 9 but neither Bax nor caspase 3. Development 128:137-146.

Galli R, Gritti A, Bonfanti L, Vescovi AL (2003) Neural stem cells: an overview. Circ Res 92:598-608.

Hayashi Y, Yamashita J, Watanabe T (2004) Molecular genetic analysis of deep-seated glioblastomas. Cancer Genet Cytogenet 153:64-68.

Hesselager G, Uhrbom L, Westermark B, Nister M (2003) Complementary effects of platelet-derived growth factor autocrine stimulation and $p 53$ or Ink4a-Arf deletion in a mouse glioma model. Cancer Res 63:4305-4309.

Holland EC (2000) A mouse model for glioma: biology, pathology, and therapeutic opportunities. Toxicol Pathol 28:171-177.

Ignatova TN, Kukekov VG, Laywell ED, Suslov ON, Vrionis FD, Steindler DA (2002) Human cortical glial tumors contain neural stem-like cells expressing astroglial and neuronal markers in vitro. Glia 39:193-206.

Jang T, Litofsky NS, Smith TW, Ross AH, Recht LD (2004) Aberrant nestin expression during ethylnitrosourea-(ENU)-induced neurocarcinogenesis. Neurobiol Dis 15:544-552.

Jori FP, Galderisi U, Piegari E, Cipollaro M, Cascino A, Peluso G, Cotrufo R, Giordano A, Melone MA (2003) EGF-responsive rat neural stem cells: molecular follow-up of neuron and astrocyte differentiation in vitro. J Cell Physiol 195:220-233. 
Katayama K, Ueno M, Yamauchi H, Nagata T, Nakayama H, Doi K (2005) Ethylnitrosourea induces neural progenitor cell apoptosis after S-phase accumulation in a $p 53$-dependent manner. Neurobiol Dis 18:218-225.

Lantos PL, Pilkington GJ (1979) The development of experimental brain tumours. A sequential light and electron microscope study of the subependymal plate. I. Early lesions (abnormal cell clusters). Acta Neuropathol (Berl) 45:167-175.

Lee Y, Chong MJ, McKinnon PJ (2001) Ataxia teleangectasia mutateddependent apoptosis after genotoxic stress in the developing nervous system is determined by cellular differentiation status. J Neurosci 21:66876693.

Leonard JR, D'Sa C, Klocke BJ, Roth KA (2001) Neural precursor cell apoptosis and glial tumorigenesis following transplacental ethyl-nitrosourea exposure. Oncogene 20:8281-8286.

Lois C, Alvarez-Buylla A (1994) Long-distance neuronal migration in the adult mammalian brain. Science 264:1145-1148.

Marino S, Vooijs M, van Der Gulden H, Jonkers J, Berns A (2000) Induction of medulloblastomas in p53-null mutant mice by somatic inactivation of $\mathrm{Rb}$ in the external granular layer cells of the cerebellum. Genes Dev 14:994-1004.

Morshead CM, Reynolds BA, Craig CG, McBurney MW, Staines WA, Morassutti D, Weiss S, van der Kooy D (1994) Neural stem cells in the adult mammalian forebrain: a relatively quiescent subpopulation of subependymal cells. Neuron 13:1071-1082.

Nait-Oumesmar B, Decker L, Lachapelle F, Avellana-Adalid V, Bachelin C, Van Evercooren AB (1999) Progenitor cells of the adult mouse subventricular zone proliferate, migrate and differentiate into oligodendrocytes after demyelination. Eur J Neurosci 11:4357-4366.

Oda H, Zhang S, Tsurutani N, Shimizu S, Nakatsuru Y, Aizawa S, Ishikawa T (1997) Loss of $p 53$ is an early event in induction of brain tumors in mice by transplacental carcinogen exposure. Cancer Res 57:646-650.

Parker MA, Anderson JK, Corliss DA, Abraria VE, Sidman RL, Park KI, Teng YD, Cotanche DA, Snyder EY (2005) Expression profile of an operationally-defined neural stem cell clone. Exp Neurol 194:320-332.

Peretto P, Merighi A, Fasolo A, Bonfanti L (1999) The subependymal layer in rodents: a site of structural plasticity and cell migration in the adult mammalian brain. Brain Res Bull 49:221-243.

Philipp-Staheli J, Kim KH, Liggitt D, Gurley KE, Longton G, Kemp CJ (2004) Distinct roles for $p 53$, p27Kip1, and p21Cip1 during tumor development. Oncogene 23:905-913.

Picard-Riera N, Nait-Oumesmar B, Baron-Van Evercooren A (2004) Endogenous adult neural stem cells: limits and potential to repair the injured central nervous system. J Neurosci Res 76:223-231.

Rao MS (1999) Multipotent and restricted precursors in the central nervous system. Anat Rec 257:137-148.
Recht L, Jang T, Savarese T, Litofsky NS (2003) Neural stem cells and neurooncology: quo vadis? J Cell Biochem 88:11-19.

Reilly KM, Loisel DA, Bronson RT, McLaughlin ME, Jacks T (2000) Nf1; Trp53 mutant mice develop glioblastoma with evidence of strain-specific effects. Nat Genet 26:109-113.

Reynolds BA, Rietze RL (2005) Neural stem cells and neurospheres-reevaluating the relationship. Nat Methods 2:333-336.

Reynolds BA, Weiss S (1992) Generation of neurons and astrocytes from isolated cells of the adult mammalian central nervous system. Science 255:1707-1710.

Savarese TM, Jang T, Low HP, Salmonsen R, Litofsky NS, Matuasevic Z, Ross $\mathrm{AH}$, Recht LD (2005) Isolation of immortalized, INK4a/ARF-deficient cells from the subventricular zone after in utero $N$-ethyl- $N$-nitrosourea exposure. J Neurosurg 102:98-108.

Slikker III W, Mei N, Chen T (2004) N-ethyl-N-nitrosourea (ENU) increased brain mutations in prenatal and neonatal mice but not in the adults. Toxicol Sci 81:112-120.

Sung T, Miller DC, Hayes RL, Alonso M, Yee H, Newcomb EW (2000) Preferential inactivation of the $p 53$ tumor suppressor pathway and lack of EGFR amplification distinguish de novo high grade pediatric astrocytomas from de novo adult astrocytomas. Brain Pathol 10:249-259.

Toda M, Iizuka Y, Yu W, Imai T, Ikeda E, Yoshida K, Kawase T, Kawakami Y, Okano H, Uyemura K (2001) Expression of the neural RNA-binding protein Musashi1 in human gliomas. Glia 34:1-7.

van Lookeren Campagne M, Gill R (1998) Tumor-suppressor p53 is expressed in proliferating and newly formed neurons of the embryonic and postnatal rat brain: comparison with expression of the cell cycle regulators p21Waf1/Cip1, p27Kip1, p57Kip2, p16Ink4a, cyclin G1, and the protooncogene Bax. J Comp Neurol 397:181-198.

Vitry S, Avellana-Adalid V, Lachapelle F, Evercooren AB (2001) Migration and multipotentiality of PSA-NCAM+ neural precursors transplanted in the developing brain. Mol Cell Neurosci 17:983-1000.

von Deimling A, Eibl RH, Ohgaki H, Louis DN, von Ammon K, Petersen I, Kleihues P, Chung RY, Wiestler OD, Seizinger BR (1992) p53 mutations are associated with $17 \mathrm{p}$ allelic loss in grade II and grade III astrocytoma. Cancer Res 52:2987-2990.

von Deimling A, Louis DN, Wiestler OD (1995) Molecular pathways in the formation of gliomas. Glia 15:328-338.

Watanabe K, Tachibana O, Sata K, Yonekawa Y, Kleihues P, Ohgaki H (1996) Overexpression of the EGF receptor and p53 mutations are mutually exclusive in the evolution of primary and secondary glioblastomas. Brain Pathol 6:217-223.

Zheng T, Steindler DA, Laywell ED (2002) Transplantation of an indigenous neural stem cell population leading to hyperplasia and atypical integration. Cloning Stem Cells 4:3-8. 